\title{
НТС - ЭМИГРАНТСКАЯ ЭКСТРЕМИСТСКАЯ ГРУППА? К ВОПРОСУ О ТИПОЛОГИИ ПОЛИТИЧЕСКИХ ОРГАНИЗАЦИЙ РУССКОГО ЗАРУБЕЖЬЯ 1
}

\section{NTS - AN EXTREMIST EXTREME GROUP? TO THE QUESTION ABOUT THE TYPOLOGY OF POLITICAL ORGANIZATIONS IN RUSSIAN ABROAD}

\section{A. Antoshin \\ V. Antoshin}

Summary: The article presents an analysis of the problem of the typology of political organizations in the Russian emigration, understanding the issue of the nature and specifics of political extremism in the Russian emigration. The focus is on the history of the NTS, the most famous emigrant organization of the Cold War era. It is shown that the problem of the typology of political organizations in the Russian Diaspora is one of the most controversial topics in historiography. The authors argue that elements of extremism were characteristic of the NTS both in the 1930s and after the Second World War.

Keywords: Russian emigres, political organizations, NTS, Cold War, extremism.
$\mathrm{H}$ ачавшийся в конце 1980-х гг. исследовательский бум в области изучения истории Русского зарубежья уже к концу 1990-х - началу 2000-х гг. привел к пониманию необходимости более глубокого концептуального осмысления данного феномена. Так, в дискуссионном поле оказалась проблематика типологии эмигрантских политических организаций. Пожалуй, особенно сложной задачей была классификация тех многочисленных структур, которые создавались при активном участии т.н. «незамеченного поколения» - русской молодежи 1920-1930-х гг., выросшей уже в условиях эмиграции. Большинство из этих организаций располагались в правой части идейно-политического спектра, что отражало непопулярность левых (в традиционном понимании) идеологических течений в молодежной эмигрантской среде.

Особое место в политической истории Русского зарубежья занимала организация, наиболее известная как НTC, хотя в реальности ее название не раз менялось.
Антошин Алексей Валерьевич

Д.и.н., профессор, Уральский Федеральный Университет Антошин Валерий Алексеевич

К.ф.н., профессор, Уральский Институт Управления РАНХИГС alex_antoshin@mail.ru

Аннотация: В статье представлен анализ проблемы типологии политических организаций Русского зарубежья, осмысление вопроса о природе и специфике политического экстремизма в русской эмиграции. В центре внимания история HTC, наиболее известной эмигрантской организации эпохи холодной войны. Показано, что проблема типологии политических организаций Русского зарубежья относится к числу весьма дискуссионных сюжетов в историографии. Авторы доказывают, что элементы экстремизма были характерны для НТС как в 1930-е гг., так и после Второй мировой войны.

Ключевые слова: русская эмиграция, политические организации, НTС, холодная война, экстремизм.

Считающая себя преемником эмигрантских молодежных организаций 1920-х гг., она провел свой I съезд в 1930 г. как Национальный союз русской молодежи (НСРМ). На II съезде в 1931 г. организация была переименована в Национальный союз нового поколения (НСНП). Весной 1936 г. лидеры данной структуры уточнили ее название, превратив ее в Национально-трудовой союз нового поколения (НТСНП). Ставка на «новое поколение» - эмигрантскую молодежь - привела к тому, что довоенный НТС часто именовался в эмигрантской прессе «нацмальчиками». В начале 1940-х гг. слова «нового поколения» выпали из названия данной структуры, а в 1957 г., как пишет многолетний член организации Б. С. Пушкарев, «В угоду принятому в СССР словоупотреблению», она стала называться Народно-трудовым союзом (российских солидаристов) [4, с. 11]. Под аббревиатурой НТС Союз известен уже более полувека.

Все эти переименования, бесспорно, носили не только формальный характер: они отражали и определенную

Исследование выполнено в рамках гранта РФФИ № 19-59-51004 «Роль диаспоральных сообществ в социально-экономическом и культурном развитии России и Кореи в XX в. (на материалах сообществ русских эмигрантов в Корее и корейской общины урала)». 
идейную эволюцию Союза. Это обстоятельство необходимо учитывать при анализе тех попыток типологии НТС как политической организации, который уже были предприняты в исторической литературе. Так, например, А.Ф. Киселев - автор-составитель известной хрестоматии по политической истории русской эмиграции, вышедшей в 1999 г., считает довоенный НТСНП одной из ключевых праворадикальных эмигрантских структур, помещая его в один ряд с такими объединениями, как Русский национальный союз участников войны (РНСУВ) и Российское народно-имперское (штабс-капитанское) движение. Эти организации А.Ф. Киселев отделяет от правоцентристов (РОВС, Торгово-промышленный союз и т.д.) и «пореволюционных течений (к которым он относил, прежде всего, младороссов).

При этом А.Ф. Киселев, на наш взгляд, справедливо отмечает идеологическую близость НТСНП и к тому, и к другому указанным выше типам. С «пореволюционерами» «нацмальчиков» объединяло, отмечал он, признание невозможности реставрации «дореволюционного порядка вещей», «подчеркнутый идеократизм», «резкое отталкивание от старшего поколения эмиграции» и ставка на идею «национальный революции». Однако, в отличие от младороссов, НТСНП представлял себе национальную революцию не как постепенную трансформацию советской системы, «нацмальчики» были лишены всяких иллюзий в отношении эволюции политического режима в СССР, свойственных лидерам младороссов. Для членов НТСНП «национальная революция» представляла собой «насильственный слом» советской системы [5, с. 337].

По мнению деятелей НТСНП, антибольшевистскую борьбу можно было вести, замечает А. Ф. Киселев, «любыми путями и средствами», что сближало их с руководством РОВС. Однако последнее воспринималось «нацмальчиками» как излишне архаичное в идейном плане, а также недостаточно политически активное, что, как справедливо указывает исследователь, было связано и с пресловутым «конфликтом отцов и детей» [5, с. 337].

Иная типология эмигрантских политических организаций представлена в монографии П.Н. Базанова, вышедшей уже в 2000-е гг. Он различает новоструктурные (новотактические) и идеократические (новоидеологические) группы. К первым он относит очень разные структуры от возглавлявшегося П.Н. Милюковым Республиканско-демократического объединения (РДО) до Братства Русской правды и монархистов. Эти группы, по замечанию П.Н. Базанова, были созданы из существовавших до революции и во время Гражданской войны организаций, которые «изменили в эмиграции свою структуру и стратегию, но питались старой идеологией». Они возникали как блоки групп (остатков старых партий), где признавалось личное и коллегиальное членство [1, с. 89].
П.Н. Базанов относит НТСНП к иному типу - идеократических (новоидеологических) структур, которые также включали в себя, по его мнению, младороссов, РНСУВ, русских фашистов и т.д. Они рождались на рубеже 19201930-х гг. в ходе «поиска принципиально новых идеологий». При этом, как полагает петербургский историк, будущую Россию эти группы видели «идеократическим» государством, где «правящая политическая организация включена в государственную структуру, а идеология проникает во все формы жизни». При этом П.Н. Базанов указывает, что отличительной особенностью идеократических течений была их «пореволюционность», т.е. признание факта революции. Все «пореволюционные» группы сходились, по его мнению, на двух постулатах: «принципиальное отрицание возможности реставрации в России дореволюционного государственного строя» и «попытки найти в революции 1917 г. положительные черты, которыми можно воспользоваться в идеологической борьбе» [1, с. 159].

Указанные выше типологии, прежде всего, отражали ситуацию в довоенном Союзе. Уже на его II съезде в декабре 1931 г. была принята директива «Тактика работы НСНП», посвященная методам, которые планировалось использовать в борьбе с политическим режимом в СССР. «Нацмальчики» прямо указывали, что они признают «революционные методы борьбы», «до террора включительно». Они призывали население России к «революционной самодеятельности» [7, с. 44].

При этом первоначально члены НТС пытались сотрудничать с уже существовавшими эмигрантскими организациями, исповедовавшими стратегию т.н. «активизма» - РОВС, БРП и «Крестьянской Россией». Но довольно быстро стала очевидна иллюзорность представлений о том, что эти группы занимались активной борьбой против большевизма. Как известно, советские спецслужбы активно проникали в эмигрантскую среду, имея своих агентов, в том числе, и среди видных деятелей РОВС. Такая широко известная акция, как операция «Трест», показала: нередко эмигрантский «активизм» фактически направлялся из Москвы.

В этих условиях Союз сделал ставку на самостоятельную подготовку к осуществлению «национальной революции». Следует подчеркнуть, что, по мнению деятелей НTC, иного способа ликвидации существовавшего в Советском Союзе режима не существовало: «коммунистическую власть можно устранить лишь насильственным путем, т.е. революцией» $[7$, с. 65].

В середине 1930-х гг., после III съезда Союза, эти идеи получают дальнейшее развитие. Лидеры НСНП-НТСНП заявляли, что центр тяжести в антибольшевистской борьбе переносится «в Россию» - с целью создания «революционного подполья» [7, с. 71]. 
«Сомкнем ряды наперекор тиранам,

На штурм, бойцы, стремительным тараном!», -

пелось в союзной песне тех лет.

Во второй половине 1930-х гг. НТСНП наладил выпуск листовок, которые пытался перебрасывать в СССР. В воззваниях к молодежи особенно подчеркивались свойственный ей энтузиазм, жертвенность, смелость и готовность на подвиги. Во многих листовках давались практические советы - как организовывать малые боевые группы (3-5 человек), готовить оружие. Как отмечают сами деятели Союза Л.А. Рар и В.А. Оболенский, в условиях «ежовщины» особенно возросло значение идей ответного террора против представителей власти [7, с. 95].

После Второй мировой войны НТС, казалось, эволюционировал в респектабельную право-демократическую партию типа Христианско-демократического союза в Германии. Тем не менее, активно сотрудничая с ЦРУ, деятели Союза и в годы холодной войны пытались использовать довоенный опыт организации перехода агентов через советскую границу. Предпринимались даже попытки проникновения в СССР путем заброски парашютистов. Самым известным случаем такого рода были арест советскими спецслужбами и расстрел в 1953 г. группы, состоявшей из С.З. Горбунова, А.В. Лахно, А.Н. Макова и Д.Н. Ремиги. Их гибель вызвала широкий резонанс в среде российской эмиграции. О реакции лидеров НТС на известие о расстреле молодых товарищей свидетельствовали названия статей в солидаристской прессе: «Это на нас», «Наша боль» [3, с. 1-4] и т.д. Как отмечает в своих воспоминаниях Б. С. Пушкарев, после гибели этой группы парашютистов значительно ухудшились и отношения НТС с эмигрантскими молодежными организациями: «Родители стали считать, что НТС посылает молодежь на заведомую смерть. Следовал вывод: «Если я моего мальчика люблю, я его никогда в скауты не отдам, потому что скауты - это прямой путь в НТС, а оттуда его пошлют в Россию и там его убьют» [6, с. 14]. В результате руководством Союза было принято решение о прекращении подобных акций.

Характеризуя методы агитационно-пропагандистской работы НТС в годы холодной войны, следует указать на использование им упрощенных лозунгов, рассчитанных на то, что потенциальной базой оппозиции в СССР являлась не только интеллигенция, но и те люди, которые не получили основательной общенаучной и гуманитарной подготовки. Многие из них слабо разбирались в сложных философских и идеологических конструкциях, в особенностях программ различных политических организаций. Кроме того, по мнению идеологов НTC, политическое сознание советского человека сформировалось под влиянием официальной пропаганды, оно было наиболее восприимчиво к определенным конструкциям, поэтому целесообразно было прибегнуть к тем моделям, которые давно и успешно использовались пропагандистским аппаратом в Советском Союзе.

Снижение интеллектуального уровня публикаций HTC, уменьшение удельного веса в них непосредственной пропаганды идеологических принципов солидаризма приводило к тому, что оппозиция в СССР лишалась духовного «стержня». Тот факт, что пропаганда НТС среди советских людей основывалась на «голом активизме», отмечал на Втором поместном съезде Северо-Американского отдела Союза в 1953 г. видный солидарист Б.В. Прянишников. Совершенно справедливо, на наш взгляд, замечание Б.В. Прянишникова о неэффективности и неконструктивности исключительно негативной платформы: «Упор на «против чего», вернее - «против кого», упор на самую голую идею революционной борьбы...Крайняя бедность материалами, отражающими идеологическое лицо и душу НТС» [2, л. 40].

По нашему мнению, не следует, однако, вслед за Б.В. Прянишниковым преувеличивать и степень разработанности идеологических вопросов в довоенном НТС. Очевидно, что «нацмальчиков» отличал бескомпромиссный антибольшевизм, особое внимание к вопросам пропаганды своих идей среди советских граждан. Неслучайно, именно солидаристы составляли особые указания по содержанию предназначенных для распространения в СССР листовок. Последние, как отмечали деятели НТС, должны были быть «кратки, ясны, просты, хлестки, бить не в бровь, а в глаз». Вместе с тем, содержание многих из них состояло из стереотипных призывов к свержению большевистской власти. На наш взгляд, они в большей степени были ориентированы на упрощенную трактовку ситуации в Советском Союзе и методов борьбы с существовавшим там режимом: «Долой красное самодержавие! Лучше перебить кучку сталинцев и повернуть дело по разумному пути, чем всем пропадать!» [5, с. 353]. Более того, еще в 1930-е гг. солидаристы прямо заявляли: «В борьбе с большевиками цель оправдывает средства!» $[5$, c. 350].

Таким образом, по нашему мнению, те негативные тенденции, которые характерны для деятельности НТС после Второй мировой войны, были заметны в деятельности Союза еще в 1930-е гг. Эмигрантский «активизм» очень часто перерождался в экстремизм, что было свойственно не только НТС, но и некоторым другим подобным структурам. Готовность использовать в борьбе против большевизма любые средства зачастую вела к беспринципности и оправданию терроризма. Именно это было одной из причин того, что даже многие инакомыслящие интеллигенты в СССР стремились отмежевываться от связей с НТС. Во многом эти черты сформировали в исторической памяти России негативный образ НТС как организации, запятнавшей себя сотрудничеством и с генералом А.А. Власовым, и с ЦРУ. 


\section{ЛИТЕРАТУРА}

1. Базанов П.Н. Издательская деятельность политических организаций русской эмиграции (1917-1988 гг.). СПб.: СПБГУКИ, 2008. 468 с.

2. В Второй поместный съезд Северо-Американского отдела НТС (1953) // Государственный архив Российской Федерации (ГАРФ). Ф. 10032. Оп. 1. д. 33.

3. За Россию. Франкфурт-на-Майне, 1953. № 5.

4. От Зарубежья до Москвы. Народно-Трудовой Союз (НТС) в воспоминаниях и документах. 1924-2014. М.: НП «Посев», 2014. 384 с.

5. Политическая история русской эмиграции. 1920-1940 гг.: Документы и материалы / Под ред. А.Ф. Киселева. М.: ВЛАДОС, 1999.776 с.

6. Посев. 2002. № 12.

7. Рар Л.А., Оболенский В.А. Ранние годы. Очерк истории Национально-Трудового Союза (1924-1948). М.: Посев, 2003. 192 с.

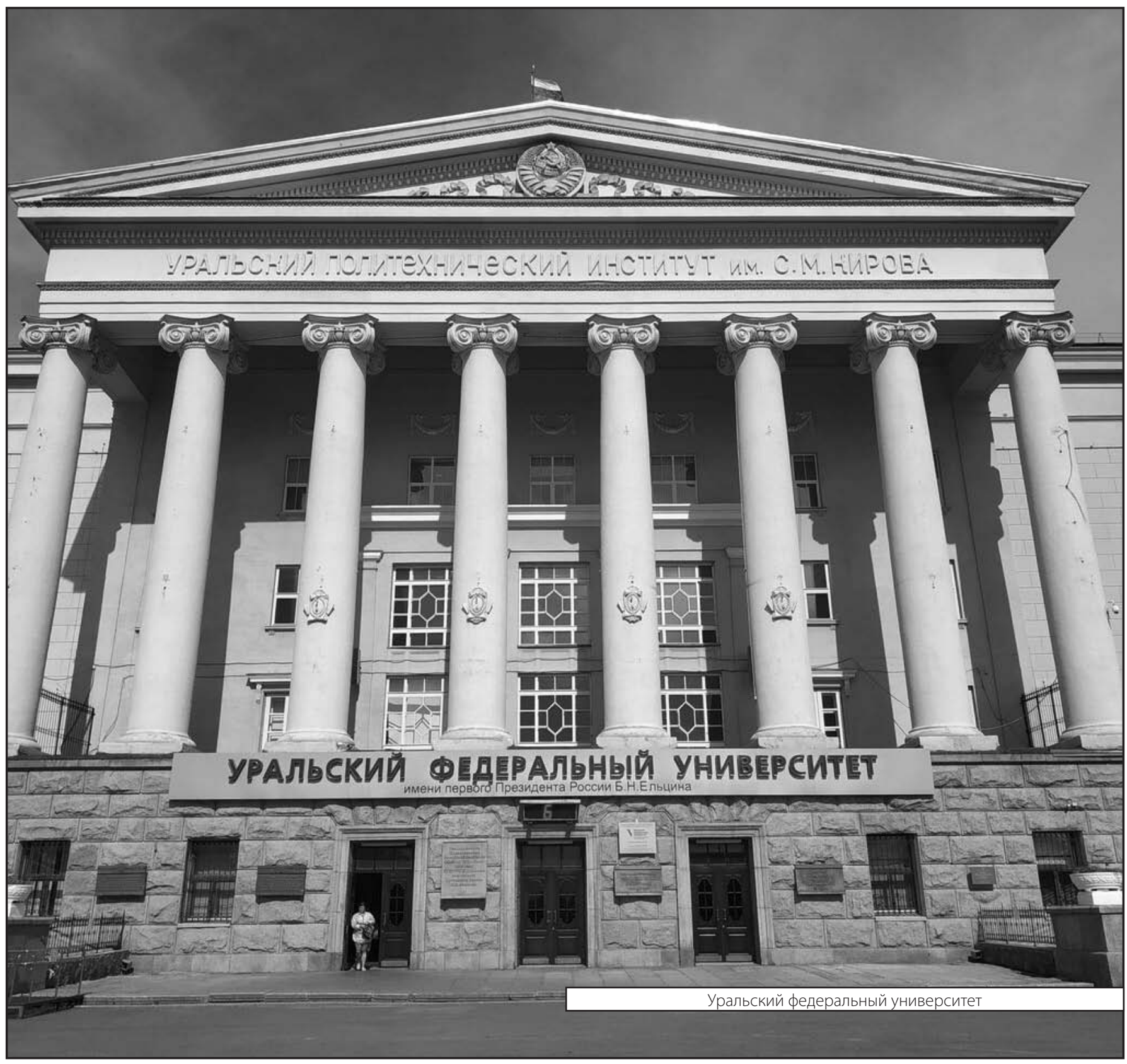

